\title{
ANALISA PENULARAN COVID-19 PADA PERAWAT DI RUMAH SAKIT
}

\section{ANALYSIS OF COVID-19 TRANSMISSION TO NURSES IN THE HOSPITAL}

\author{
Seriga Banjarnahor \\ Program Studi Ilmu Keperawatan, STIKes Murni Teguh Medan \\ Email: serigabanjarnahor@yahoo.com
}

\begin{abstract}
Abstrak
COVID-19 masih menjadi wabah yang belum teratasi diseluruh dunia. Perawat sebagai salah satu tenaga kesehatan yang bekerja di garis depan pelayanan kesehatan sangat beresiko terpapar COVID-19. Hingga saat ini, perawat yang meninggal akibat terpapar COVID-19 telah meningkat jumlahnya. Penelitian ini bertujuan untuk menganalisa pola penularan COVID-19 pada perawat. Jenis penelitian yang digunakan adalah penelitian kuantitatif dengan desain deskriptif analitik. Responden penelitian berjumlah 31 perawat, yang diperoleh dengan menggunakan teknik total sampling. Hasil penelitian ini menunjukkan bahwa penularan COVID-19 pada perawat terjadi karena adanya riwayat kontak dengan pasien COVID-19 (80,6\%), kebiasaan makan bersama dengan rekan kerja $(67,7 \%)$, merawat pasien yang terkonfirmasi COVID-19 di ruangan non isolasi $(67,7 \%)$, riwayat kontak dengan petugas rumah sakit yang terkonfirmasi COVID-19 $(51,6 \%)$, dan mengunjungi tempat keramaian seperti pasar $(45,2 \%)$.
\end{abstract}

Kata kunci: covid-19, penularan, perawat, rumah sakit

\begin{abstract}
COVID-19 is still an outbreak that has not been resolved throughout the world. Nurses as one of the health workers who work at the forefront of health services are at risk of being exposed to COVID-19. Until now, the number of nurses who died as a result of exposure to COVID-19 has increased. This study aims to analyze the modes of transmission of COVID-19 in nurses. This type of research is quantitative research with analytic descriptive design. The number of respondents in the study was 31 nurses, which were obtained by using total sampling technique. The results of this study indicate that the transmission of COVID-19 to nurses occurs due to a history of contact with COVID-19 patients (80,6\%), eating habits with colleagues $(67,7 \%)$, treating patients with confirmed COVID-19 in a non-isolation room $(67,7 \%)$, history of contact with hospital staff confirmed COVID-19 (51,6\%), and visiting crowded places such as markets (45,2\%)
\end{abstract}

Keywords: covid-19, transmission, nurses, hospital 


\section{PENDAHULUAN}

Corona Virus Disease 2019 (COVID19) masih menjadi wabah yang belum teratasi di seluruh dunia. Kasus COVID-19 pertama kali terjadi pada bulan Desember 2019 di Kota Wuhan, China. Wabah COVID-19 disebabkan oleh virus yang bernama Severe Acute Respiratory Syndrome Coronavirus 2 (SARS-CoV-2) yang memiliki asal ekologis dari populasi kelelawar. Virus ini menyebabkan penyakit pernapasan pada manusia, dari flu biasa hingga penyakit yang lebih serius seperti Severe Acute Respiratory Syndrome (SARS) dan Middle East Respiratory Syndrom (MERS), yang mana keduanya terdeteksi untuk pertama kali pada tahun 2003 dan 2012. Hingga saat ini, jumlah kasus COVID-19 semakin hari semakin meningkat di berbagai negara di dunia.

World Health Organization (2020) melaporkan bahwa kasus COVID-19 yang telah dikonfirmasi di dunia sampai dengan tanggal 19 Juni 2020, yakni sebanyak 8,3 juta kasus. Jumlah total pasien COVID-19 yang meninggal ada sebanyak 450.686 orang. Untuk kasus positif COVID-19 di Indonesia sampai dengan tanggal 19 Juni 2020 ada sebanyak 43.803 kasus. Terjadi peningkatan sebanyak 1.041 kasus dari hari sebelumnya. Untuk jumlah total pasien yang sembuh ada sebanyak 17.349 orang, sedangkan jumlah pasien positif COVID-19 yang meninggal dunia adalah sebanyak 2.373 orang (Kemenkes, 2020).

\section{Seiring kasus COVID-19 yang terus menerus meningkat, perhatian masyarakat di Indonesia tentang tingkat keparahan penyakit dan kerentanan terhadap populasi yang terpapar juga meningkat khususnya bagi tenaga kesehatan. Perawat sebagai salah satu tenaga kesehatan yang bekerja di Rumah Sakit atau Fasilitas Kesehatan lainnya}

sangat beresiko terpapar COVID-19 (Li, Peng, Wang, Ping, Zhang, \& Fu, 2020). Pada tanggal 12 April 2020, Dewan Perawat Internasional (ICN) pertama kali melaporkan bahwa lebih dari 100 perawat telah meninggal karena COVID19. Pembaruan ICN pada tanggal 6 Mei menunjukkan bahwa 90.000 petugas kesehatan telah terinfeksi dan lebih dari 260 perawat telah meninggal. Pada 3 Juni, jumlah kematian perawat telah meningkat menjadi lebih dari 600 perawat. Perawat dan petugas kesehatan lainnya berada di garis depan perawatan kesehatan yang sangat berpeluang untuk terinfeksi COVID-19 (ICN, 2020).

Banyaknya jumlah peningkatan kasus COVID-19 yang terjadi dari hari ke hari, mengharuskan Rumah Sakit untuk membuka layanan perawatan COVID-19. Murni Teguh Memorial Hospital sebagai salah satu Rumah Sakit Swasta di Kota Medan membuka layanan COVID-19 pertama kali pada bulan Maret 2020. Sebelum pelayanan ini di buka, pihak rumah sakit telah mempersiapkan Sumber Daya Manusia (SDM), fasilitas dan alur dalam melakukan pelayanan pada pasien COVID-19 serta melakukan pemaparan langkah-langkah pencegahan kepada staf. Namun, risiko staf untuk terpapar tidak bisa dihilangkan mengingat kondisi pandemi ini. Pada bulan Juni 2020, diketahui untuk pertama kalinya bahwa ada staf Murni Teguh Memorial Hospital yang terkonfirmasi COVID-19 yang terdeteksi melalui pemeriksaan RT-PCR. Hingga saat ini, sumber penularan COVID-19 masih sulit dipahami karena ada beberapa tenaga keperawatan yang meninggal dunia atau terkonfirmasi positif COVID-19 bukan berasal dari ruangan khusus perawatan COVID-19. Berdasarkan hal tersebut, penting untuk melakukan analisa sumber penularan COVID-19 khususnya pada tenaga keperawatan di rumah sakit 


\section{METODE}

Jenis penelitian yang digunakan adalah deskriptif analitik. Penelitian ini dilakukan di Murni Teguh Memorial Hospital pada bulan Juli-Agustus 2020. Populasi penelitian ini yaitu seluruh perawat Murni Teguh Memorial Hospital yang mengalami COVID-19. Teknik pengambilan sampel yang digunakan adalah total sampling. Jumlah sampel pada penelitian ini, yaitu sebanyak 31 orang.

Pengumpulan data dalam penelitian ini, yaitu melalui penyebaran kuesioner data demografi, dan kuesioner Penularan COVID-19 pada perawat dengan menggunakan google form yang dikirimkan secara pribadi ke masingmasing responden penelitian. Kuesioner data demografi terdiri dari inisial nama, usia, jenis kelamin, unit kerja, riwayat penyakit, dan penyakit komorbid. Untuk kuesioner Penularan COVID-19 pada perawat, dibagi menjadi 2 (dua) bagian, yakni pertanyaan terkait perilaku di rumah sakit dan di luar rumah sakit. Pertanyaan terkait perilaku di rumah sakit berisi 9 (sembilan) item dan pertanyaan terkait perilaku di luar rumah sakit berisi 8 item. Kuesioner ini berbentuk pilihan berganda. Kuesioner ini di modifikasi dari kuesioner World Health Organization (WHO) yang berjudul Health workers exposure risk assessment and management in the context of COVID19 virus
Data yang telah terkumpul melalui lembar kuesioner, kemudian diolah peneliti melalui empat tahapan, yaitu editing, coding, entry data, dan cleaning. Hasil penelitian ini dianalisa dengan menggunakan analisa deskriptif melalui distribusi frekuensi dan persentase data yang meliputi data demografi dan prevalensi penularan COVID-19 tenaga perawat. Proses analisis dilakukan dengan menggunakan komputerisasi dengan menghasilkan tabel output berupa deskriptif data dan tabel distribusi frekuensi

\section{HASIL}

Responden yang terlibat dalam penelitian ini, yakni perawat Murni Teguh Memorial Hospital yang terkonfirmasi positif COVID-19, yakni berjumlah 31 orang. Diketahui bahwa sebagian besar perawat berada pada kelompok usia 2635 tahun, yaitu sebanyak 15 orang (48,4\%). Mayoritas perawat berjenis kelamin perempuan, yakni sebanyak 27 orang $(87,1 \%)$. Untuk unit kerja, ditemukan bervariasi, namun mayoritas perawat yang terpapar COVID-19 berasal dari ruang rawat inap, yakni sebanyak 16 orang (51,6\%). Mengenai riwayat penyakit dan penyakit komorbid, mayoritas responden tidak memiliki riwayat penyakit, yakni sebanyak 26 orang (83,9\%). Distribusi Frekuensi dan Persentase Karakteristik Respon secara rinci di tampilkan dalam tabel 1 berikut ini. 
Tabel 1.

Distribusi Frekuensi Karakteristik Responden ( $\mathrm{n}=31$ )

\begin{tabular}{lcc}
\hline Karakteristik Responden & N & Persen (\%) \\
\hline Umur & 11 & 35,5 \\
$17-25$ tahun & 15 & 48,4 \\
$26-35$ tahun & 3 & 9,7 \\
$36-45$ tahun & 2 & 6,5 \\
$46-55$ tahun & & \\
\hline Jenis Kelamin & 27 & 87,1 \\
Perempuan & 4 & 12,9 \\
Laki-laki & & \\
\hline Unit Kerja & 1 & 3,2 \\
Poliklinik & 16 & 51,6 \\
Rawat Inap & 2 & 6,5 \\
Intensif Care & 2 & 6,5 \\
Unit Gawat Darurat & 4 & 12,9 \\
Hemodialisa & 2 & 6,5 \\
Paliative & 1 & 3,2 \\
Onkologi & 2 & 6,5 \\
Operating Theater & 1 & 3,2 \\
Wound Care & & \\
\hline Riwayat Penyakit & 5 & 16,1 \\
Ada & 26 & 83,9 \\
Tidak Ada & & \\
Penyakit Komorbid & 26 & 3,9 \\
Tidak Ada & 1 & 3,2 \\
Transient Ischemic Attack & 1 & \\
Infeksi Saluran Kemih & & \\
Sinusitis & & \\
Diabetes Melitus & & \\
\hline & & \\
\hline
\end{tabular}

Kuesioner penularan COVID-19 di berikan kepada 31 perawat di Murni Teguh Memorial Hospital. Hasil penyebaran kuesioner bagian I mengenai perilaku di rumah sakit memperoleh data bahwa sebanyak 25 orang $(80,6 \%)$ memiliki riwayat kontak dengan pasien COVID-19, sebanyak 16 orang (51,6\%) memiliki riwayat kontak dengan petugas RS terkonfirmasi COVID-19. Sebanyak 24 orang $(77,4 \%)$ sudah menggunakan Alat Pelindung Diri (APD) yang sesuai dan selalu patuh menggunakan APD saat melakukan tindakan kepada pasien. Sebanyak 25 orang $(80,6 \%)$ selalu melakukan kebersihan tangan. Untuk kebiasaan makan saat istirahat, sebanyak
21 orang $(67,7 \%)$ memiliki kebiasaan makan bersama dengan teman di meja kerja. Sebanyak 21 orang $(67,7 \%)$ merawat pasien terkonfirmasi COVID-19. Sebanyak 18 orang $(58,1 \%)$ tidak melakukan tindakan yang bersifat aerosol, sebanyak 20 orang $(64,5 \%)$ sudah menggunakan APD yang sesuai saat melakukan tindakan yang bersifat aerosol.

Hasil penyebaran kuesioner bagian II, memperoleh data bahwa sebanyak 29 orang $(93,5 \%)$ tidak tinggal dengan orang yang terkonfirmasi positif COVID-19. Sebanyak 27 orang $(87,1 \%)$ tidak tinggal di lingkungan yang terkonfirmasi COVID-19. Sebanyak 29 
orang $(93,5 \%)$ tidak ada mengikuti kegiatan sosial selama 14 hari sebelum hasil RT-PCR keluar. Sebanyak 28 orang (90,3\%) melaksanakan Ibadah dirumah. Untuk tempat keramaian yang dikunjungi, mayoritas mengunjungi pasar yakni sebanyak 14 orang $(45,2 \%)$. Pelaksanaan protokol kesehatan yang salah satunya menjaga jarak telah selalu dilakukan oleh responden yakni sebanyak $23(74,2 \%)$, Keseluran responden (100\%) mengkonsumsi vitamin dan tidak memiliki riwayat sebagai seorang perokok. Distribusi frekuensi dan persentase penularan COVID-19 pada perawat di rumah sakit, dapat dilihat secara lengkap pada tabel dibawah ini.

Tabel 2.

Distribusi Frekuensi dan Persentase Penularan COVID-19 pada Perawat $(n=31)$

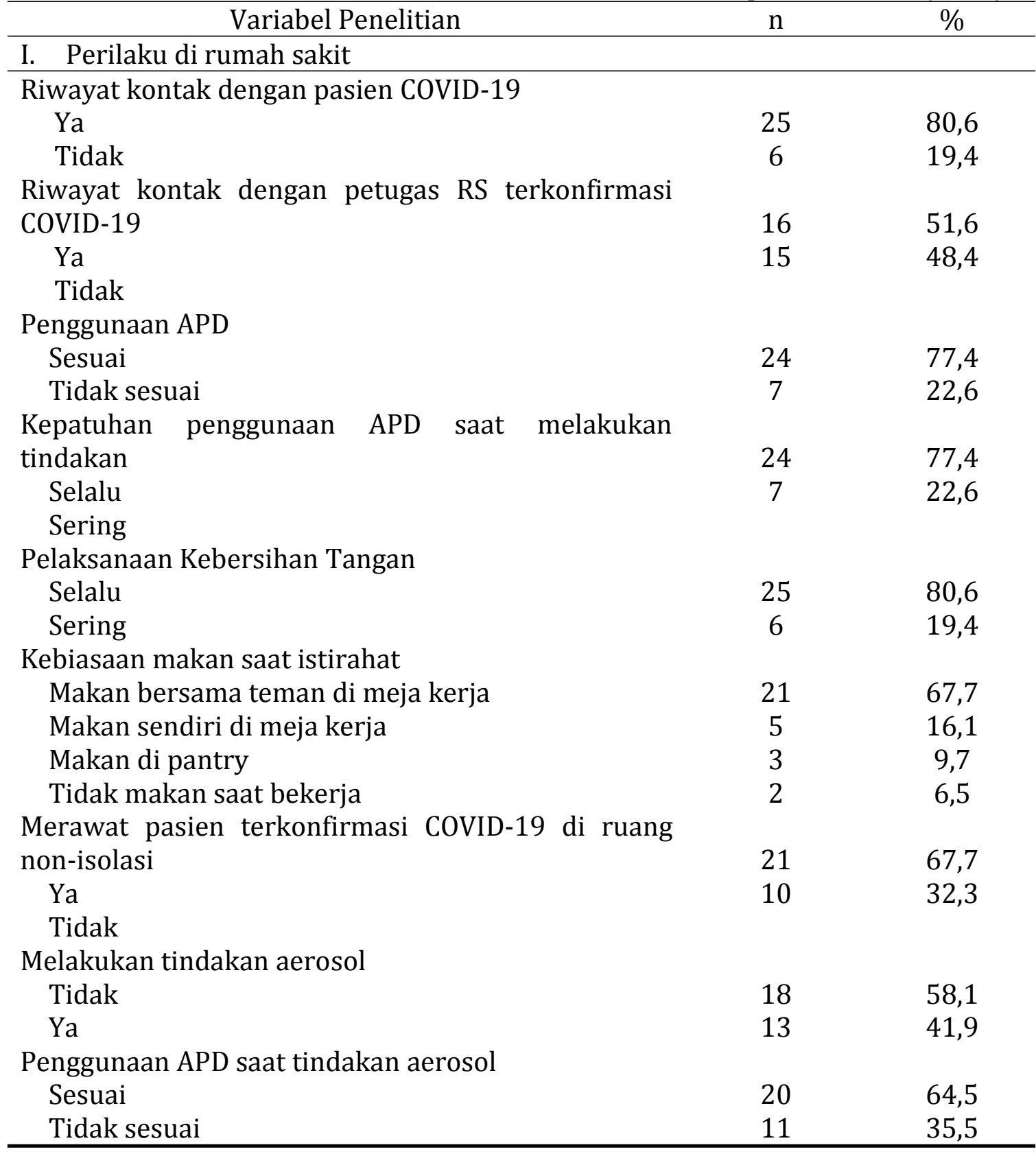

II. Perilaku diluar rumah sakit

Tinggal dengan orang terkonfirmasi COVID-19 


\begin{tabular}{lcc}
\hline Tidak & 29 & 93,5 \\
Ya & 2 & 6,5 \\
Tinggal di lingkungan yang terkonfirmasi COVID-19 & & \\
$\quad$ Tidak & 27 & 87,1 \\
$\quad$ Ya & 4 & 12,9 \\
Kegiatan sosial yang diikuti & 29 & 93,5 \\
$\quad$ Tidak ada & 1 & 3,2 \\
Arisan lingkungan & 1 & 3,2 \\
Wirit & & \\
Pelaksanaan Ibadah & 28 & 90,3 \\
$\quad$ Dirumah & 3 & 9,7 \\
Pergi ke rumah Ibadah & & \\
Tempat keramaian yang dikunjungi & 14 & 45,2 \\
$\quad$ Pasar & 5 & 16,1 \\
Mall & 3 & 9,7 \\
Cafe & 9 & 29 \\
Tidak ada & & \\
Menjaga jarak dengan orang lain & 23 & 74,2 \\
Selalu & 7 & 22,6 \\
Sering & 1 & 3,2 \\
Kadang-kadang & & \\
Mengkonsumsi vitamin & 31 & 100 \\
Ya & & \\
Merokok & 31 & 100 \\
Tidak & & \\
\hline
\end{tabular}

\section{PEMBAHASAN}

COVID-19 memiliki tingkat infeksifitas yang sangat tinggi. Hasil penelitian ini menunjukkan bahwa penularan COVID-19 pada perawat terjadi karena adanya riwayat kontak dengan pasien dan petugas rumah sakit yang terkonfirmasi COVID-19, kebiasaan makan bersama dengan rekan kerja, merawat pasien yang terkonfirmasi COVID-19 di ruangan non isolasi, dan mengunjungi tempat keramaian seperti pasar.

Penelitian yang dilakukan oleh Jin et al. (2020) menunjukkan bahwa rute penularan dari 39 kasus yaitu terjadi melalui kontak dengan rekan kerja. Penularan COVID-19 dimulai dari infeksi hewan ke manusia, namun virus ini telah berkembang sehingga menjadi bentuk yang dapat menyebabkan penularan cepat dari manusia ke manusia. Penyebaran virus dari manusia ke manusia terjadi karena melakukan kontak dekat dengan orang yang terinfeksi, baik terkena batuk, bersin, atau aerosol. Aerosol ni dapat menembus tubuh manusia terutama paru-paru melalui inhalasi melalui hidung atau mulut. Coronavirus juga menunjukkan tingkat transmisi lebih tinggi daripada SARS dikarenakan terjadinya rekombinasi genetik yang telah meningkatkan kemampuan transmisi (Shereen et al, 2020).

Menurut Tellier, Li, Cowling, \& Tang (2019) penularan COVID-19 melalui aerosol, droplet, dan kontak langsung. Penularan melalui aerosol diduga menjadi mode penularan utama. Aerosol merupakan partikel dengan diameter 
dibawah $100 \mu \mathrm{m}$. Transmisi melalui udara berkontribusi terhadap kejadian COVID-19. Temuan menunjukkan bahwa transmisi COVID-19 di udara sejalan dengan laporan kejadian SARS di masa lalu (Sheng et al, 2020)

Penularan nosokomial pasien COVID-19 di pelayanan kesehatan dapat dikontrol dengan melakukan tindakan pengamanan atau pengendalian yang memadai seperti melakukan kebersihan tangan, penggunaan APD dan mematuhi protokol kesehatan yang telah ditetapkan oleh pemerintah (Rahman et al, 2020). Hal ini sejalan dengan penelitian Chou et al (2020) dari 64 studi memenuhi kriteria inklusi, 43 penelitian membahas beban infeksi tenaga kesehatan dan 34 penelitian membahas faktor risiko. Dari hasil penelitian diperoleh bahwa tenaga kesehatan menyumbang proporsi yang signifikan dari infeksi COVID-19 dan mungkin mengalami insiden infeksi yang sangat tinggi setelah paparan yang tidak terlindungi. Penggunaan APD dan pelatihan pengendalian infeksi dikaitkan dengan penurunan risiko infeksi, dan eksposur tertentu dikaitkan dengan peningkatan risiko.

Saat ini, perawat secara aktif terlibat dalam intervensi COVID-19, dan perawat akan tetap menjadi pemain kunci dalam menghentikan pandemi dengan bantuan yang memadai. Oleh karena itu, perawat harus disediakan lingkungan kerja yang sehat untuk memberdayakan upaya mereka dalam pengendalian dan penanggulangan wabah. Keselamatan kerja adalah kunci pekerjaan perawat selama COVID-19, karena mereka berhadapan langsung dengan bahaya setiap hari. Tugas utama manajemen keperawatan adalah memastikan pencegahan dan langkah keamanan yang tepat telah diambil untuk mengurangi bahaya di tempat kerja. Dalam hal ini, rumah sakit harus memiliki prosedur pengendalian infeksi yang tepat dan peralatan pelindung diri (masker, sarung tangan, kacamata, gaun pelindung, handrub/hand sanitizer, sabun dan air, dan bahan pembersih lainnya) dalam jumlah yang cukup bagi personel yang merawat pasien yang terkonfirmasi COVID-19.

Supervisor keperawatan harus memberikan pengetahuan tentang keamanan tempat kerja, instruksi dan panduan mengenai pencegahan dan pengendalian infeksi, bagaimana cara memakai, melepaskan, dan membuang peralatan pelindung diri dengan benar. Dalam hal ini, anggota staf juga harus dibimbing tentang bagaimana melakukan penilaian diri secara teratur, dan diarahkan pada bagaimana mengikuti tindakan karantina atau isolasi, jika diindikasikan, untuk melindungi mereka, keluarga mereka, dan komunitas mereka, serta untuk menjaga keamanan, kesehatan mental dan kesejahteraan mereka (Fawaz, Anshasi \& Samaha, 2020).

Tenaga kesehatan secara alami berisiko tinggi terhadap infeksi COVID-19 karena pajanan di tempat kerja yang mungkin terjadi beberapa kali dalam pengaturan perawatan kesehatan atau saat memberikan perawatan kepada pasien COVID-19. Penularan juga dapat terjadi di area nonmedis rumah sakit saat berbicara atau makan. Oleh karena itu, skrining petugas kesehatan secara berkala, bahkan ketika tidak menunjukkan gejala dan terutama di antara mereka yang berisiko tinggi untuk penularan SARS-CoV-2, dapat memungkinkan deteksi dini dan isolasi petugas kesehatan (Çelebi et al, 2020). Selain skrining, manajer perawat harus siap menghadapi dampak pandemi pada staf dan perlu memastikan ketersediaan dan penggantian alat pelindung diri yang berkualitas, melatih strategi untuk berkomunikasi dengan pasien saat 
mengenakan alat pelindung diri dan menetapkan protokol untuk berkomunikasi dengan kerabat (Catania, 2020).

\section{SIMPULAN}

Penularan COVID-19 pada perawat umumnya terjadi karena adanya riwayat kontak dengan pasien COVID-19 (80,6\%), kebiasaan makan bersama dengan rekan kerja $(67,7 \%)$, merawat pasien yang terkonfirmasi COVID-19 di ruangan non isolasi $(67,7 \%)$, riwayat kontak dengan petugas rumah sakit yang terkonfirmasi COVID-19 (51,6\%), dan mengunjungi tempat keramaian seperti pasar $(45,2 \%)$.

Saran dalam penelitian ini, yakni sebaiknya perawat tetap patuh dalam menjalankan protokol kesehatan yang telah ditetapkan oleh pemerintah dan juga rumah sakit mengenai penggunaan Alat Pelindung Diri (APD), kebersihan tangan dan jaga jarak agar dapat mengurangi penyebaran COVID-19.

\section{REFERENSI}

Catania, G., Zanini, M., Hayter, M., Timmins, F., Dasso, N., Ottonello, G., Aleo, G., Sasso, L., \& Bagnasco, A. (2020). Lessons from Italian frontline nurses' experiences during the COVID-19 pandemic: A qualitative descriptive study. Journal of nursing management, https://doi.org/10.1111/jonm.1319 4

Çelebi, G., Pişkin, N., Çelik Bekleviç, A., Altunay, Y., Salcı Keleș, A., Tüz, M. A., Altınsoy, B., \& Hacıseyitoğlu, D. (2020). Specific Risk Factors for SARS-CoV-2 Transmission Among Health Care Workers in a University Hospital. American Journal of Infection Control, 48(10), 12251230. https://doi.org/10.1016/j.ajic.2020. 07.039

Chang, Le., Yan, Y., Wang, L. (2020). Coronavirus Disease 2019: coronaviruses and blood safety. Transfusion Medicine Reviews.

Chou, R., Dana, T., Buckley, D. I., Selph, S., Fu, R., \& Totten, A. M. (2020). Epidemiology of and Risk Factors for Coronavirus Infection in Health Care Workers: A Living Rapid Review. Annals of internal medicine, 173(2), 120-136. https://doi.org/10.7326/M20-1632

Fawaz, M., Anshasi, H., \& Samaha, A. (2020). Nurses at the Front Line of COVID-19: Roles, Responsibilities, Risks, and Rights. The American journal of tropical medicine and hygiene, 103(4), 1341-1342. https://doi.org/10.4269/ajtmh.200650 .

Guan et al. (2020). Clinical Characteristics of Coronavirus Disease 2019 in China. The New England Journal of Medicine.

https://doi.org/10.1016/j.tmrv.202 0.02 .003

International Council of Nurses. (2020). Protecting Nurses from COVID-19 a Top Priority: A Survey of ICN's National Nursing Association.

Keputusan Menteri Kesehatan Republik Indonesia. (2020). Pedoman Pencegahan dan Pengendalian Corona Virus Disease 2019 (COVID19)

Li, Y-k., Peng, S., Li, L-q., Wang, Q., Ping, W., Zhang, N., \& Fu, X-n. (2020). Clinical transmission characteristic of Covid-19 - A restrospective atudy of 25 cases from a single thoracic 


\section{surgery department. Current \\ Medical Science, $40 \quad$ (2). \\ https://doi.oorg/10.1007/s11596- \\ 020-2176-2}

Persi. (2020). Pneumonia COVID-19:

Diagnosis \& Penatalaksanaan di Indonesia. Jakarta: Perhimpunan Dokter Paru Indonesia.

Shen, Y., Li, C., Dong, H., Wang, Z., Martinez, L., Sun, Z., \& Wang, F. (2020). Airborne transmission of COVID-19: Epidemiologic Evidence from Two Outbreak Investigations.

Shereen, M.A., Khan, S., Kazmi, A., Bashir, N. \& Siddique, R. (2020). COVID -19 Infection: Origin, Transmission, and Characteristics of Human Coronaviruses'. Journal of Advanced Research, vol. 24, pp. 91-8

Tellier, R., Li, Y., Cowling, B. J., \& Tang, J. W. (2019). Recognition of aerosol transmission of infectious agents: a commentary. BMC Infectious Diseases. https://doi.org/10.1186/s12879019-3707-y

Wang, W., Xu, Y., Gao, R., Lu, R., Han, K., Wu, G., Tan, W., (2020). Detection of SARS-CoV-2 in different types of clinical specimens. J. Am. Med. Assoc. https://doi.org/10.1001/jama.2020. 3786

World Health Organization. (2020). Modes of transmission of virus causing COVID-19: implications for IPC precaution recommendations. Diakses dari https://www.who.int 